\title{
Heterocyclic Spiro-Compounds from Tandem Cascade Reaction of Alkyl Azides and Methyl Vinyl Ketone
}

\author{
Chia-Hsi Yang ${ }^{\mathrm{a} *}$ ( 楊嘉喜), Lang-Tong Lee ${ }^{\mathrm{a}}$ ( 李蓮童) and Yu Wang (王 瑜) \\ a Department of Chemistry, Chung-Yuan Christian University, Chung-Li 320, Taiwan, R.O.C. \\ ${ }^{\mathrm{b}}$ Department of Chemistry, National Taiwan University, Taipei 106, Taiwan, R.O.C.
}

\begin{abstract}
Tandem cascade reaction of one molecule of alkyl azide and four molecules of methyl vinyl ketone gives a heterocyclic compound having an 1,4-diazepine fused to a pyrazoline and spiro-linked to a dihydropyran. The tandem cascade reaction is composed of an intermolecular [3+2] dipolar cycloaddition to give a triazoline, an isomerization to a diazo compound, another intermolecular [3+2] dipolar cycloaddition to give a pyrazoline, a Michael addition, dehydration, and a [4+2] cycloaddition.
\end{abstract}

Keywords: Tandem cascade reaction; One-pot reaction; [3+2] Dipolar cycloaddition; [4+2] Cycloaddition.

\section{INTRODUCTION}

Synthesis based on tandem cascade reaction can be an efficient process for preparing organic compounds. ${ }^{1-6}$ This strategy has been extended to syntheses of many heterocycles. $^{7-9}$ The reaction of alkyl or aryl azide with alkenes carrying an electron-withdrawing group was found to be a tandem cascade reaction. ${ }^{10}$ For example, butyl azide reacts with ethyl acrylate to give $\Delta^{2}$-pyrazolines $\mathbf{3 a}$, an adduct from one molecule of azide and two molecules of acrylate. (1+2 adduct). L'abbe et al. proposed a pathway consisting of an intermolecular dipolar cycloaddition to give a triazoline $\mathbf{1}$, an isomerization to give a diazo compound $\mathbf{2}$, and another intermolecular 1,3-dipolar cycloaddition of $\mathbf{2}$ to acrylate to give $\mathbf{3}$. (Scheme I).

In our previous study on the reaction of alkyl azide with methyl vinyl ketone (MVK) or ethyl vinyl ketone (EVK) using tetrahydrafuran (THF) as the solvent, we reported spiro compounds $(\mathbf{5 b}$ or $\mathbf{5 c}$ ) containing a pyrazoline ring and a piperidine ring were obtained in a fair yields. ${ }^{11} \mathbf{5 b}$ is an adduct from one molecule of alkyl azide and three molecules of MVK. $(1+3$ adduct). We proposed that the pathway of the reaction is the same as that of the $1+2$ adduct in the beginning $(\mathbf{1} \rightarrow \mathbf{2} \rightarrow$ 3 ) followed by a Michael addition of $\mathbf{3}$ to MVK to give an enolate $\mathbf{4 b}$ and then an intramolecular cyclization to give $\mathbf{5 b}$ (Scheme I).

In this report, another tandem cascade reaction involving one molecule of alkyl azide and four molecules of MVK to give a heterocyclic compound having an 1,4-diazepine fused to a pyrazoline and spiro-linked to a dihydropyran is presented.
Scheme I
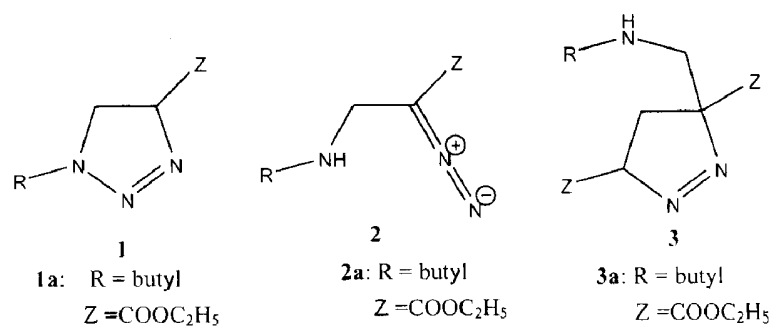

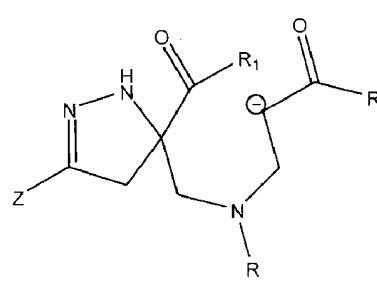

4

$\mathrm{R}=$ alkyl

4b $\mathrm{R}_{1}=\mathrm{CH}_{3} . \mathrm{Z}=\mathrm{COCH}_{3}$

4c: $\mathrm{R}_{1}=\mathrm{CH}_{2} \mathrm{CH}_{3}, \mathrm{Z}=\mathrm{COCH}_{2} \mathrm{CH}_{3}$

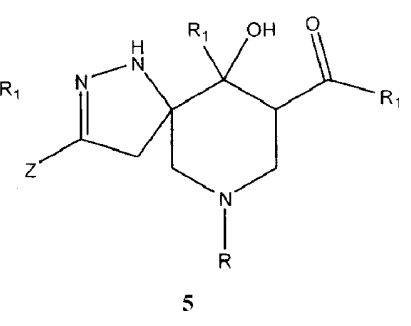

$\mathrm{R}=$ alkyl

5b: $\mathrm{R}_{1}=\mathrm{CH}_{3} \mathrm{Z}=\mathrm{COCH}_{3}$

5c: $\mathrm{R}_{1}=\mathrm{CH}_{2} \mathrm{CH}_{3}, \mathrm{Z}=\mathrm{COCH}_{2} \mathrm{CH}_{3}$

\section{RESULTS AND DISCUSSIONS}

During our study on the reaction concerning 1+3 adduct, in one experiment, THF, which was supposed to be the solvent in the reaction, was forgotten to be added to the reactants. Thus, only butyl azide and MVK were mixed and allowed to stir for 3 days. From viscous crude product, a compound, which apparently was not $\mathbf{5}$, was obtained. The high resolution mass spectrum, ${ }^{1} \mathrm{H}$ and ${ }^{13} \mathrm{C}$ NMR spectra of this 
compound are consistent with the molecular formula of $\mathrm{C}_{20} \mathrm{H}_{31} \mathrm{~N}_{3} \mathrm{O}_{3}$, and indicate that the product is an adduct from one molecule of butyl azide and four molecules of MVK followed by dehydration (1+4 adduct). With the help of HMQC and $\mathrm{HMBC}$, we were able to conclude that the structure of this compound should be as shown for $\mathbf{9 e}$, a structure having an 1,4-diazepine fused to a pyrazoline and also spiro-linked to a dihydropyranyl ring. However, for a complex structure of this degree, we were not so sure this assignment was the only possibility. In addition, there are stereochemical problems concerning the acetyl substituent at 3'a-position and the dihydropyran spiro-linked to the 8 '-position. Therefore, a single crystal X-ray diffraction analysis was carried out. The result (Fig. 1) confirmed that the assignment of structure to 9e was correct. The diazepine ring adopts a chair conformation. The 3'a-acetyl substituent and the dihydropyranyl oxygen bonded to the diazepine ring are in an axial and equatorial position, respectively.

In the absence of solvent, $1+4$ adduct, but no $1+3$ adduct, could be isolated from the reaction of butyl azide and MVK. Care had been taken to check the existence of $1+3$ adduct in the crude product by ${ }^{1} \mathrm{H}$ NMR, but no trace of it was observed. On the contrary, in the presence of THF as the solvent, only $1+3$ adduct was obtained and no $1+4$ adduct was observed in the crude product. Propyl azide and benzyl azide reacting with MVK also produce compounds with the same structure (9d and 9f). We had tried to extend the reaction to include other azides and alkyl vinyl ketone. To our disappointment, we found that, in the absence of solvent, both with the reaction of propyl azide and EVK, and the reaction of toluenesulfonyl azide and MVK, only $1+3$ adduct could be obtained, ${ }^{11}$ and no $1+4$ adduct was isolated. Thus it seems that in the reaction of azide and vinyl ketone, a bulky sub-

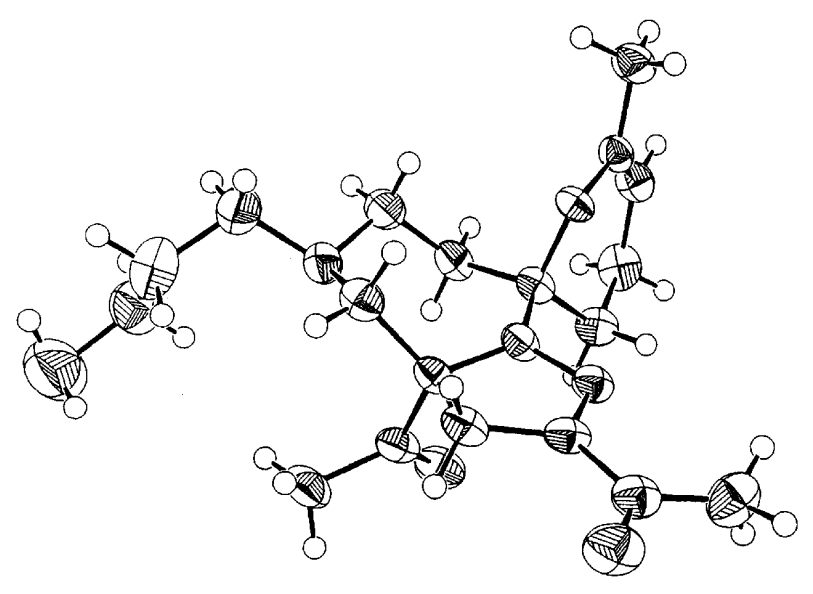

Fig. 1. ORTEP of $9 \mathbf{e}$. stituent on either reactant blocks the pathway to the $1+4$ adduct.

We believe that compound 9 is a product from the following pathway (Scheme II). At the beginning, the same pathway as $1+2$ adduct is taken $(\mathbf{1} \rightarrow \mathbf{2} \rightarrow \mathbf{3})$. A Michael addition of $\mathbf{3}$ to MVK gives $\mathbf{6}$. Intramolecular cyclization of $\mathbf{6}$ gives 7 . Dehydration of $\mathbf{7}$ gives $\mathbf{8}$, a compound with a methylene-1,4-diazepine fused to pyrazoline. Finally, a $[4+2]$ cycloaddition between MVK and $\mathbf{8}$ gives $\mathbf{9}$.

\section{Scheme II}

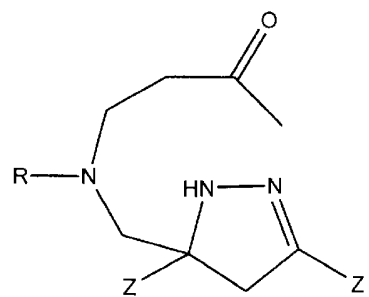

6

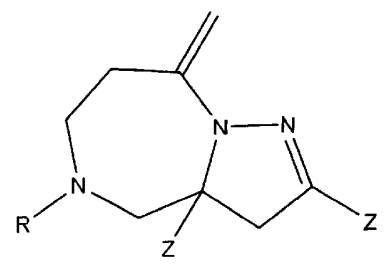

8

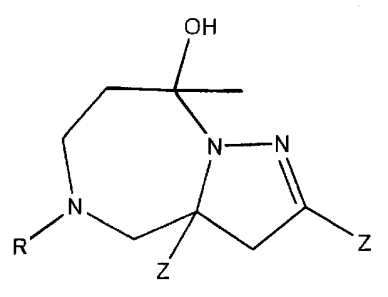

7

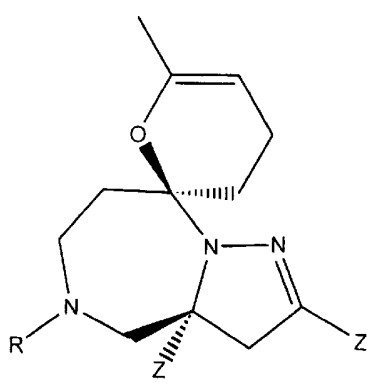

9

9d: $\mathrm{R}=$ propyl

9e: $\mathrm{R}=$ butyl

9f: $R=$ benzyl
The mechanism is supported by the following facts. (a) Examples of $\alpha, \beta$-unsaturated carbonyl compound and enamine undergo [4+2] cycloaddition to give 6-amino-2,3-dihydropyran are reported in the literature. ${ }^{13}$ The regiochemistry of the resulting dihydropyran ring in $\mathbf{9}$ is the same as reported in the literature. ${ }^{13}$ (b) The trans configuration of dihydropyranyl oxygen relative to the 2-acetyl substituent is what one would expect from the reaction of compound $\mathbf{8}$ with MVK, considering the steric hinderance from the 2-acetyl substituent in compound 8 . (c) The steric hindrance from the ethyl group of EVK in $\mathbf{6}$ supports the result that only $1+3$ adduct, but no $1+4$ adduct, can be obtained from the reaction of alkyl azides with EVK.

The yields of the reactions are only moderate. It is understandable considering many possibilities of side reactions 
in this multiple step reaction. However, we are not able to explain why the change in solvent results in such a change of the pathway.

In conclusion, heterocyclic compounds having an 1,4-diazepine fused to a pyrazoline and also spiro-linked to a dihydropyranyl ring were obtained from tandem cascade reaction of alkyl azides and MVK in the absence of solvent. Wherein a series of reactions are invoked: a [3+2] dipolar cycloaddition to give a triazoline, an isomerization to diazo compound, an intermolecular [3+2] dipolar cycloaddition to give a pyrazoline, a Michael addition, dehydration, and a [4+2] cycloaddition.

\section{EXPERIMENTAL}

Melting points were determined on a Yanagimoto micromelting point apparatus and are reported uncorrected. The ${ }^{1} \mathrm{H}$, and ${ }^{13} \mathrm{C}$ NMR spectra were obtained by a Brucker ACE-200MHz FT-NMR spectrometer. 2D NMR spectra were obtained by a Brucker ACE-300MHz FT-NMR spectrometer using INVDR2LP program. ${ }^{12}$ The mass spectra were obtained on a JEOL JMS-SX/SX 102A spectrometer operating at $12 \mathrm{ev}$. The elemental composition of compounds was determined by a JOEL JMS-SX/Sx 102A high resolution mass spectrometer.

Alkyl azides were prepared following the procedure to prepare allyl azide. $^{13}$

\section{General procedure for the reaction of alkyl azide and methyl vinyl ketone to prepare $1+4$ adduct (using propyl azide as an example)}

The mixture of $2.95 \mathrm{~g}$ propyl azide ( 36 mmole) and 19.4 g methyl vinyl ketone (288 mmole) was stirred for 3 days at room temperature. The brown viscous fluid obtained was dissolved in a mixed solvent of $n$-hexane and ether (3:1). After standing for 24 hours at room temperature, a yellow crystalline product precipitated. The crude product was washed with ether to obtain a light yellow crystalline product.

2',3a'-diacetyl-6-methyl-5'-propyl-spiro[3,4-dihydro-2H-pyran$2,8^{\prime}, 3 a^{\prime}, 4^{\prime}, 5^{\prime}, 6^{\prime}, 7^{\prime}, 8^{\prime}$-hexahydro-3'H-[1',5',8a']-triza-azulene $]$ (9d)

Yield; $28 \%$. mp. $152-154{ }^{\circ} \mathrm{C} .{ }^{1} \mathrm{H}$ NMR $\left(\mathrm{CDCl}_{3}\right): \delta 0.84$ $(\mathrm{t}, J=7.2 \mathrm{~Hz}, 3 \mathrm{H}), 1.43,1.46(\mathrm{t}$ of q of $\mathrm{AB}, J=7.2,7.2,7.2$ $\mathrm{Hz}, 2 \mathrm{H}), 1.62$ (ddd, $J=15.9,11.1,1.8 \mathrm{~Hz}, 1 \mathrm{H}), 1.71(\mathrm{~s}, 3 \mathrm{H})$, 2.0-2.12 (m, $3 \mathrm{H}), 2.14$ (ddd, $J=15.9,6.6,0.8 \mathrm{~Hz}, 1 \mathrm{H}), 2.20$ (s, 3H), $2.30(\mathrm{~s}, 3 \mathrm{H}), 2.37,2.38(\mathrm{t}$ of $\mathrm{AB}, J=7.2,5.7 \mathrm{~Hz}, 2 \mathrm{H})$, 2.48 (ddd, $J=11.1,11.1,0.8 \mathrm{~Hz}, 1 \mathrm{H}), 2.58-2.73(\mathrm{~m}, 2 \mathrm{H})$, $2.84(\mathrm{~d}, J=17.5 \mathrm{~Hz}, 1 \mathrm{H}), 2.89(\mathrm{~d}, J=13.4 \mathrm{~Hz}, 1 \mathrm{H}), 3.09$ (d, $J$ $=17.5 \mathrm{~Hz}, 1 \mathrm{H}), 3.22(\mathrm{dd}, J=13.4,1.9 \mathrm{~Hz}, 1 \mathrm{H}), 4.42(\mathrm{~s}, 1 \mathrm{H})$. ${ }^{13} \mathrm{C} \mathrm{NMR}\left(\mathrm{CDCl}_{3}\right): \delta 11.7\left(\mathrm{CH}_{3}\right), 19.7\left(\mathrm{CH}_{2}\right), 19.8\left(\mathrm{CH}_{2}\right)$, $20.1\left(\mathrm{CH}_{3}\right), 24.7\left(\mathrm{CH}_{3}\right), 24.8\left(\mathrm{CH}_{3}\right), 30.0\left(\mathrm{CH}_{2}\right), 30.6\left(\mathrm{CH}_{2}\right)$, $40.3\left(\mathrm{CH}_{2}\right), 49.7\left(\mathrm{CH}_{2}\right), 61.0\left(\mathrm{CH}_{2}\right), 63.1\left(\mathrm{CH}_{2}\right), 82.6(\mathrm{C})$, $91.0(\mathrm{C}), 94.4(\mathrm{CH}), 141.8(\mathrm{C}), 148.9(\mathrm{C}), 193.5(\mathrm{C}=\mathrm{O})$, $205.3(\mathrm{C}=\mathrm{O})$. EIMS m/z (\%) $347(\mathrm{M}, 70), 304$ (85), 234 (100); HRMS: Calcd for $\mathrm{C}_{19} \mathrm{H}_{29} \mathrm{~N}_{3} \mathrm{O}_{3}, 347.2202$. Found: 347.2203 .

\section{5'-butyl-2',3a'-diacetyl-6-methyl-spiro[3,4-dihydro-2H-pyran-

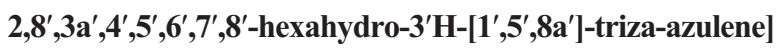

(9e)

Yield; $26 \%$. mp. $128-130{ }^{\circ} \mathrm{C},{ }^{1} \mathrm{H}$ NMR $\left(\mathrm{CDCl}_{3}\right): \delta 0.87$ $(\mathrm{t}, J=7.2 \mathrm{~Hz}, 3 \mathrm{H}), 1.20-1.43(\mathrm{~m}, 7.2 \mathrm{~Hz}, 4 \mathrm{H}), 1.62$ (ddd, $J=$ 15.8, 11.2, $2.2 \mathrm{~Hz}, 1 \mathrm{H}), 1.72(\mathrm{~s}, 3 \mathrm{H}), 2.0-2.22(\mathrm{~m}, 4 \mathrm{H}), 2.20$ $(\mathrm{s}, 3 \mathrm{H}), 2.31(\mathrm{~s}, 3 \mathrm{H}), 2.40(\mathrm{t}, J=7.2 \mathrm{~Hz}, 2 \mathrm{H}), 2.48(\mathrm{dd}, J=$ 11.0, 11.0 Hz, 1H), 2.56-2.77 (m, 2H), 2.85 (d, $J=17.6 \mathrm{~Hz}$, 1H), $2.88(\mathrm{~d}, J=13.5 \mathrm{~Hz}, 1 \mathrm{H}), 3.09$ (d, $J=17.6 \mathrm{~Hz}, 1 \mathrm{H}), 3.23$ $(\mathrm{dd}, J=13.5,1.7 \mathrm{~Hz}, 1 \mathrm{H}), 4.43(\mathrm{~s}, 1 \mathrm{H}) .{ }^{13} \mathrm{C} \mathrm{NMR}\left(\mathrm{CDCl}_{3}\right): \delta$ $13.9\left(\mathrm{CH}_{3}\right), 19.7\left(\mathrm{CH}_{2}\right), 20.2\left(\mathrm{CH}_{3}\right), 20.6\left(\mathrm{CH}_{2}\right), 24.8\left(\mathrm{CH}_{3}\right)$, $24.9\left(\mathrm{CH}_{3}\right), 28.9\left(\mathrm{CH}_{2}\right), 30.2\left(\mathrm{CH}_{2}\right), 30.7\left(\mathrm{CH}_{2}\right), 40.4\left(\mathrm{CH}_{2}\right)$, $49.9\left(\mathrm{CH}_{2}\right), 58.9\left(\mathrm{CH}_{2}\right), 63.2\left(\mathrm{CH}_{2}\right), 82.7(\mathrm{C}), 91.1(\mathrm{C}), 94.5$ (CH), $141.9(\mathrm{C}), 149.1(\mathrm{C}), 193.7(\mathrm{C}=\mathrm{O}), 205.4(\mathrm{C}=\mathrm{O})$. EIMS $\mathrm{m} / z(\%) 361$ (M, 37), 318 (50), 248 (100); HRMS: Calcd for $\mathrm{C}_{20} \mathrm{H}_{31} \mathrm{~N}_{3} \mathrm{O}_{3}, 361.2358$ Found: 361.2359 .

\section{Crystal data for 9e}

Yellow single crystal suitable for the collection of $\mathrm{X}$-ray diffraction data was obtained by recystallization from ether. A crystal $(0.3 \times 0.45 \times 0.55 \mathrm{~mm})$ was mounted on Enraf-Nonius CAD-4 automated four-circle diffractometer. The crystal was found to be monoclinic, space group $\mathrm{P} 2{ }_{1} / \mathrm{c}$, unit cell dimensions: $\mathrm{a}=11.0451(20) \AA, \mathrm{b}=15.815(5) \AA, \mathrm{c}=$ 11.5169(20) $\AA ; \beta=94.012^{\circ}(15), \mathrm{V}=2007.3(8) \AA^{3} ; \underline{\mathrm{d}}_{\mathrm{calcd}}=$ $1.196 \mathrm{~g} / \mathrm{cm}^{3}(\mathrm{Z}=4)$; radiation Mo-K $\alpha$; limits ( $\left.\max \right) 23.3^{\circ}$, total reflection scanned 2614, 2614 unique reflections, 1657 observed reflections with $\mathrm{F}>2 \sigma(\mathrm{F}) ; \mathrm{R}=0.047 ; \mathrm{R}_{\mathrm{w}}=0.046$; 236 refined parameters. List of positional and anisotropic thermal parameters of non-hydrogen atoms, positional and thermal parameters of hydrogen atoms, bond distances and bond angles are available upon request.

5'-benzyl-2',3a'-diacetyl-6-methyl-spiro[3,4-dihydro-2H-pyran-

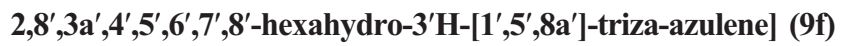
Yield; $16 \%$ mp. $162-164{ }^{\circ} \mathrm{C} .{ }^{1} \mathrm{H}$ NMR $\left(\mathrm{CDCl}_{3}\right): \delta$ 1.65-1.67 (m, 1H), $1.72(\mathrm{~s}, 3 \mathrm{H}), 2.06-2.17(\mathrm{~m}, 4 \mathrm{H}), 2.06(\mathrm{~s}$, $3 \mathrm{H}), 2.32(\mathrm{~s}, 3 \mathrm{H}), 2.49(\mathrm{dd}, J=12.2,11.0 \mathrm{~Hz}, 1 \mathrm{H}), 2.66(\mathrm{~m}$, 2H), $2.84(\mathrm{~d}, J=17.6 \mathrm{~Hz}, 1 \mathrm{H}), 2.92(\mathrm{~d}, J=13.2 \mathrm{~Hz}, 1 \mathrm{H}), 3.07$ 
(d, $J=17.6 \mathrm{~Hz}, 1 \mathrm{H}), 3.29(\mathrm{~d}, J=13.2,1 \mathrm{H}), 3.55(\mathrm{~s}, 2 \mathrm{H}), 4.42$ (s, 1H). 7.22-7.33 (m, 5H). ${ }^{13} \mathrm{C} \mathrm{NMR}\left(\mathrm{CDCl}_{3}\right)$ : $\delta 19.7\left(\mathrm{CH}_{2}\right)$, $20.1\left(\mathrm{CH}_{3}\right), 24.5\left(\mathrm{CH}_{3}\right), 24.9\left(\mathrm{CH}_{3}\right), 30.1\left(\mathrm{CH}_{2}\right), 30.5\left(\mathrm{CH}_{2}\right)$, $40.4\left(\mathrm{CH}_{2}\right), 50.1\left(\mathrm{CH}_{2}\right), 62.5\left(\mathrm{CH}_{2}\right), 63.3\left(\mathrm{CH}_{2}\right), 82.5(\mathrm{C})$, $91.1(\mathrm{C}), 94.5(\mathrm{CH}), 127.4(\mathrm{CH}), 128.3(\mathrm{CH}), 129.1(\mathrm{CH})$, $137.6(\mathrm{C}), 142.0(\mathrm{C}), 149.0(\mathrm{C}), 193.5(\mathrm{C}=\mathrm{O}), 205.2(\mathrm{C}=\mathrm{O})$. EIMS m/z (\%) 395 (M, 34), 352 (41), 325 (11), 91 (100); HRMS: Calcd for $\mathrm{C}_{23} \mathrm{H}_{29} \mathrm{~N}_{3} \mathrm{O}_{3}, 395.2202$ Found: 395.2206.

Received September 5, 2002.

\section{REFERENCES}

1. Denmark, S. E.; Thorarensen, A. Chem. Rev. 1996, 96, 137.

2. Loon, J. D.; Seiler, P.; Diederich, F. Angew. Chem. Int. Ed. Engl. 1993, 32, 1706.
3. Ishikura, M.; Hino, A.; Yaginuma, T.; Agata, I.; Katagiri, N. Tetrahedron 2000, 56, 193.

4. Wada, E.; Kumaran, G.; Kanemasa, M. Tetrahedron Lett. 2000, 41, 73 .

5. Giomi, D.; Nesi, R.; Turchi, S.; Mura, E. J. Org. Chem. 2000, 65, 360 .

6. Fejes, I.; Töke, L.; Nyerges, M.; Pak, C. S. Tetrahedron 2000, 56, 639.

7. Marino, J. Jr.; Osterhout, M. H.; Price, A. T.; Semones, M. A.; Padwa, A. J. Org. Chem. 1994, 59, 5518.

8. Padwa, A.; Brodney, M. A.; Marino, J. P. Jr.; Sheehan, S. M. J. Org. Chem. 1997, 62, 78.

9. Padwa, A.; Price, A. J. Org. Chem. 1998, 63, 556.

10. Broeckx, W.; Overbergh, N.; Samyn, C.; Smets, G.; L'abbe, G. Tetrahedron 1971, 27, 3527.

11. Yang, C. H.; Lee, L. T.; Yang, J. H.; Wang, Y.; Lee, G. H. Tetrahedron 1994, 42, 12133.

12. Martin, G. E.; Crouch, R. C. J. Nat. Prod. 1991, 54, 1.

13. Yang, C. H.; Shen, H. J.; Wang, R. H.; Wang, J. C. J. Chin. Chem. Soc. 2002, 49, 95. 